\title{
'THE VOCATION OF REFORMED ETHICIST IN THE PRESENT SOUTH AFRICAN SOCIETY
}

\author{
Etienne de Villiers \\ Department of Dogmatics and Christian Ethics \\ University of Pretoria
}

\begin{abstract}
The central Reformed conviction that Christians are called by God to contribute to the transformation of society has, within a very short time span, lost much of its previous legitimacy in the South African society. In the article the factors that contributed to this loss of legitimacy are analysed. The argument is developed that the legitimacy of this Reformed conviction can only be restored by reconstructing the traditional transformation approach and by developing a more inclusive version that suits the contemporary context. One may say that contributing to the development and the implementation of such an inclusive transformation approach is the most important part of the vocation of Reformed ethicist in the present South African society. It entails contributing to the development of an adequate, contemporary Christian social ethics, the formulation of a Christian vision of a good society in South Africa based on a strong Christian consensus and the effective translation and promulgation of this Christian vision in broader society.
\end{abstract}

Key Concepts: Reformed ethics, vocation, South Africa

\section{Introduction}

The conviction that Christians are called by God to contribute to the transformation of society is central to the Reformed tradition (cf. Burger 2001:89-104; Leith 1992:8-11; Niebuhr 1951:190-229; Smit 1998:30-34; Troeltsch 1981:576-691). This conviction is based on a belief that is equally central to the Reformed tradition: God the Creator and Governor is also Lord of history. He is working out his divine purposes in human history and calls his people to be instruments in the fulfillment of his purposes. His purposes entail not only the salvation of souls, but also the establishment of a holy community and the glorification of his name through all the world (Leith 1992:8). In a world marked by sin, the Christian calling to serve these purposes of God, inevitably implies the calling to work for the transformation of the world and, more particularly, society.

This conviction has profound implications for the conception of the vocation of the Reformed ethicist. As the right actions of Christians - including their right actions in society - form the subject matter of her academic studies she cannot escape the conclusion that an important part of her vocation as ethicist is to help fellow-Christians to contribute to the transformation of society. More particularly, it is part of her vocation to indicate to her fellow-Christians what the practical implications of the gospel of Christ for the transformation of society are. Such an indication is only of real help if it is not abstract and general, but concrete and directed to the particular context and society in which they are living. 
In this chapter I explore the vocation of Reformed ethicist in the present South African society, and, more in particular, the implications of the Reformed conviction that we are called by God to contribute to the transformation of society for the implementation of her vocation. The reason is that this central conviction of Reformed faith has, within a very short time span, lost its previous legitimacy even for Reformed Christians in our society. In my opinion restoring the legitimacy of this conviction is one of the most important challenges the Reformed ethicist faces in the execution of her vocation in the present South Africa. This challenge would only be met if the conviction is given a satisfactory and convincing content, based on at least the following: An adequate, contemporary Christian social ethical theory, a strong Christian consensus on what a good society in the South African context entails and the effective translation and promulgation of this Christian vision of the good society in the broader South African society. Before turning to an explication of the vocation of the Reformed ethicist in this regard, some of the factors contributing to the loss of the named conviction's legitimacy in our society are discussed. For it is only on the basis of an adequate analysis of the factors contributing to this loss, that a satisfactory account of the vocation of the Reformed ethicist in the South African society can be given.

\section{The Loss of Legitimacy of the Transformation Approach}

In the previous political dispensation Reformed churches and theologians in South Africa differed strongly on many issues, except on one thing: Christians have God's calling to transform society in the light of the gospel of Christ. Ironically, the disputes they had with one another were mostly related to different interpretations of what this conviction implied in the South African context.

The three Afrikaans Reformed churches took their point of departure in the theocratic ideal expressed, amongst others, in Section 36 of the Confessio Belgica. According to this theocratic ideal the state is an institution of God that has to serve Him by protecting the true Christian religion against false religion, by listening to the voice of the church and by striving to serve Christian values in its policies and actions. ${ }^{1}$ As a result of the exceptionally close relationship between the Afrikaans Reformed churches and the Nationalist government the theocratic ideal did not remain a pipe dream. ${ }^{2}$ The government shared the conviction that South Africa was a Christian country and even gave expression to it in the 1983 constitution. ${ }^{3}$ It for the most part accommodated the wishes of the Afrikaans Reformed churches to introduce legislation regulating public morality - for example on abortion, censorship, gambling and trading on Sundays - that reflected their conservative moral views.

1 The theocratic ideal as part of the faith tradition of the DRC and the negative impact the transition to the new constitutional dispensation had on this ideal, is discussed in a report on "Church and state in the present constitutional dispensation" in the Proceedings of the General Synod of the Dutch Reformed Church, October 1998, pp. 83-87. See also DE de Villiers, “The influence of the DRC on public policy during the late 1980's and 1990's", Scriptura 76, 51-61.

2 In his book Ontluisterde wêreld: Die Afrikaner en sy kerk in 'n veranderde wêreld (English translation of the title: Disenchanted world: The Afrikaner and his church in a changing world) J Durand traces the roots of this close relationship back to the influence of the Reformed pietism prevalent in the Netherlands at the time Jan van Riebeeck founded a Dutch settlement at the Cape (pp. 32-39).

3 One of the national objectives set out in the constitution was "to maintain Christian values and civilised norms and to recognise and protect freedom of worship" (Lubbe 2002:64). 
Theologians and historians differ on whether the Afrikaans Reformed churches played a decisive role in formulating and instigating the apartheid policy of the Nationalist government, or only supported it once it was formulated and implemented. It cannot be denied, however, that the theological justification of apartheid by these churches was directly linked to their allegiance to the theocratic ideal. In a 1955 report on "The Scriptural basis for the apartheid of races", approved by the Dutch Reformed Church, any attempt to justify the apartheid policy solely on practical political grounds - for example on the need to preserve Western civilisation or Christianity in Southern Africa - was rejected. Views and policies on racial relationships had to be based solely on God's revealed Word as the final measure. Therefore the report set out to demonstrate that the apartheid policy was indeed - in its view - based on what the Bible prescribed (cf. De Villiers 1984:58-59).

Reformed churches and theologians who opposed apartheid and were involved in the struggle against the apartheid regime were just as convinced that the Bible condemned apartheid and that they were called by God to struggle for a new and liberated South Africa. An example is ABRECSA (Alliance of Black Reformed Christians in Southern Africa), founded in 1981. ABRECSA rejected what it considered the wrong interpretation of the Reformed tradition of the Afrikaans Reformed churches, and strived to work out the implications of what they saw as the correct interpretation. They affirmed that in the Reformation tradition (a) the Word of God is the supreme authority; (b) Jesus Christ is the Lord of the whole of life; (c) Christians bear responsibility for the world in its totality; (d) obedience to earthly authority is only obedience in God; (e) unity of the church must be visible (Boesak 1984:ix-x). On the basis of this affirmation they set out to actively oppose apartheid and the theological justification of it by the Afrikaans Reformed churches. Their opposition to apartheid prepared the way for the Declaration on Racism that the General Council of the World Alliance of Reformed Churches adopted in Ottawa in August 1982 and in which Dr Allen Boesak, chairperson of ABRECSA, played a prominent part. It declared 'that apartheid is a sin and that the moral and theological justification for it is a travesty of the gospel, a betrayal of the Reformed tradition, and a heresy'.

With the dawn of the new political dispensation in South Africa in 1994 everything changed. Within a short time span it became apparent that the conviction that Christians have a calling to transform society in accordance with the gospel has almost completely lost the self-evident nature it had for Reformed Christians in the previous political dispensation. In my opinion there are three major factors contributing to this development:

\section{Disillusionment as a result of the failed attempt by the Afrikaans Reformed churches to base apartheid on the Bible.}

Theologians, ministers and members of these churches who were initially convinced that the Bible prescribed or, at least, supported apartheid eventually had to admit that they were mistaken. In the case of many of them it resulted in a deep-seated scepticism about any attempt to transform society in the light of the biblical message.

\section{The dismantling of the credibility structures undergirding the transformation approach in the previous political dispensation.}

In the case of the Afrikaans Reformed churches this took place in a rather dramatic and even traumatic way. The old constitution that gave political legitimacy to their efforts to ensure that Christian values were recognised in government policies was abolished. The loss of political power of the National Party meant that these churches lost the sympathetic 
ear of politicians sharing the same theocratic vision. They also lost their position of privileged access to the state owned radio and television and the printed media. All of this amounted to a severe loss of social status and public influence. Many members of the Afrikaans Reformed churches experienced the loss of power of both the political party they supported and the churches to which they belonged as rather traumatic. The fact that primarily Afrikaner people experienced the brunt of accusations in the Truth and Reconciliation Commission, of retrenchment and unemployment as a result of the implementation of affirmative action in the civil service and of the threat of expropriation as a result of the new government's land reform programme, added to this experience. It led, amongst others, to what Jürgen Moltmann called the 'inward emigration' of a considerable number of the members of the Afrikaans churches (Moltmann 1974:37-41). Many of them have completely dissociated themselves from what happens in the public sphere and have withdrawn to their own private sphere of purely personal relationships, interests and religious experiences (De Villiers 1999:23-24). They do not have any desire that their churches should even try to exert a public influence.

As in the case of Germany after unification, South African churches, church leaders and theologians who actively supported the liberation struggle found that appreciation for the role they played in the apartheid era did not translate in the New South Africa into privileged public roles. It is true that quite a number of church leaders and theologians including a number with a Reformed background - were awarded with political posts for their contribution and as politicians have continued to play influential public roles. The experience of those who remained church leaders and theologians was rather one of a severe loss of public influence. Their loss of public influence was partly and ironically the result of the success of the liberation struggle. In the New South Africa it was no longer necessary for churches and church leaders to fill the political vacuum that was left with the banning of liberation organisations and the imprisonment of their leaders and to play a vicarious political leadership role. The leaders of the ANC and the PAC who were released from prison and returned from exile after 1990 took over the political leadership role and expected the churches not to interfere with politics.

\section{The introduction and entrenchment of social structures and processes influenced by modernisation.}

The one factor that maybe, more than any other, contributed to the loss of legitimacy of the transformation approach of the Reformed tradition since the dawn of the new political dispensation was the introduction of a new liberal constitution. The new liberal constitution, for the first time in South African history, clearly insists on the separation of religion and state. This makes it difficult - if not impossible - for the government to implement the distinctive views of a particular religious group, let alone the distinctive views of a particular religious denomination within that religious group. It is clear that the separation of religion and state in the New South Africa has - up till now - caused considerable confusion and uncertainty among churches that were used to direct involvement in public matters. In the present political dispensation the state is seen as a purely human institution that has to obey the will of the majority, may not favour any particular religion, has to promote a set of common human values expressed in the bill of rights and has to ensure religious freedom to all religious institutions (De Villiers 2001:51-52). Apparently, the view that society should be transformed in accordance with the Christian gospel, is discredited by the new liberal constitution as politically illegitimate. 
The separation of religion and state is but one example of the entrenchment of pluralism in the present South Africa. Already in the previous political dispensation the influence of modernisation could not be completely abated. Especially in the eighties it became clear that not only politics, but also other social systems like economics, science and the arts, increasingly asserted their independence from religion and moral systems other than the liberal. With the dawn of the New South Africa the demise of the theocratic worldview of the Reformed tradition and the introduction of a liberal constitution allowed modernisation processes, including pluralism, to proceed seemingly unabatedly. The autonomy of the different social systems, even of a social system such as education that was previously strongly based on Christian religious values, has been increasingly acknowledged. The concomitant result was the increasing loss of legitimacy of the traditional Reformed conviction that all spheres of life should be brought to obedience to the law of God.

On a personal level the increasing influence of individualism can be noticed in the South African society. Cultural globalisation, the increasing influence on local culture of factors originating in other parts of the world (cf. Tomlinson 1999:106-149), has, amongst others, led to the spread of both utilitarian individualism, which entails the devotion to the calculating pursuit of one's own material interest and expressive individualism, which stresses the freedom to express oneself, against all constraints and conventions (cf. Bellah 1995:32-35), also among members of the Reformed churches.

The result of the dismantling of credibility structures and increasing modernisation is that the transformation approach has not only lost much of its legitimacy in broader society, but also for many members of the Reformed churches. One even notices within the South African Reformed churches the increasing adherence to two other traditional approaches that stand in opposition to the transformation approach of the Reformed tradition: The 'two kingdom' approach of Lutheranism, which accepts that other principles apply to politics and economics than Biblical principles, and the sectarian approach, which conceives society as evil and hostile and denies the social ethical responsibility of Christians.

\section{Reconstructing the Transformation Approach}

What implications does the loss of legitimacy of the transformation approach have for the vocation of Reformed ethicist in the present South African society? Should she abolish the effort to develop a distinctively Christian social ethics that strives to contribute to the transformation of the South African society and concentrate her academic efforts on the development of a purely personal or intra-church Christian ethics? Or should she rather, in order to ensure the continuing social relevance of the church in South Africa, develop a Christian rationale for promoting the implementation of liberal values, as Peter Beyer suggests (Beyer 2001:273)?

In my opinion there is no need to abolish the transformation approach of the Reformed tradition. However, this approach has to be reformed in turn. We have to take leave of what I call the exclusive version of the transformation approach that was often dominant in the past. And we have to develop a more inclusive version that critically takes account of modernisation processes taking place in the world and in South Africa in particular. In my opinion the development of such a contemporary, inclusive version entails at least the following tasks for the Reformed ethicist in the South African context: 
The development of an adequate, contemporary Christian social ethics

A Christian social ethics based on the exclusive transformation approach strives to christianise society. It is exclusive in more than one way:

- It strives to christianise society by expecting the explicit recognition of the Lordship of Christ in all social spheres on the basis of a particular Christian confession, usually the Reformed confession.

- It regards the moral values of the Bible as the sole and final measure for policy formation and action in all social spheres.

As long as all members of society profess the Reformed faith and agree on the implications of the recognition of the Lordship of Christ for the different social spheres, the christianising of society needs not be problematic. It becomes problematic when differences on the implications of the recognition of Christ's Lordship surface among Reformed Christians. It becomes more problematic when Christians from other confessions have to accept the Reformed interpretation of what the christianising of society entails. And it becomes highly problematic when the recognition of Christ's Lordship is expected from non-Christians. As soon as a society is characterised by a plurality of Christian social visions and confessions, religions and non-religious worldviews a particular Reformed view of the christianising of society can only be realised by authoritarian enforcement and by disregarding the freedom of conscience of persons.

As a result of these problems experienced with the christianising of society as goal of the transformation approach Reformed theologians influenced by Karl Barth have proposed that the goal should rather be the humanising of society. ${ }^{4}$ The humanising of society is a goal with which non-Christians can also identify. As Barth, however, demonstrated in Christengemeinde und Bürgergemeinde the humanising of society does not necessarily mean the acceptance of a universally recognised set of criteria. Christians can still develop their own criteria for the humanising of society. The only problem with humanising as goal of the transformation of society is that it is not comprehensive enough. It reflects an anthropocentric bias and does not include the enhancement of the well-being of other living creatures. The Reformed ethicist therefore has to be on the lookout for a more suitable and inclusive goal for the transformation of society. The optimal protection and enhancement of all life on earth or the flourishing of all God's creatures are formulations of a more inclusive goal that may be worthwhile to explore.

In his famous paper Politik als Beruf (English: Politics as vocation) published in 1919 Max Weber convincingly took to task those Christians who regard their own interpretation of the moral message of the Bible as the sole and final measure of political policies and actions. In this paper he specifically criticised Christian pacifist politicians who campaigned for the abolishment of the German army on the basis of their understanding of the sermon on the mount. He depicted them as proponents of an Ethics of Conviction (German: "Gesinnungsethik"). According to Weber it is typical of proponents of such an ethics to apply their religiously inspired moral convictions in an abstract and absolute way without taking into account: The specific nature of politics, the particular role responsibility that they as politicians have and the disastrous consequences a decision to abolish the

In Christengemeinde und Bürgergemeinde Barth has the following to say about the purpose of the state: "Die in seiner Existenz stattfindende Auswirkung göttlicher Anordnung besteht darin, dass es da Menschen (ganz abgesehen von Gottes Offenbarung und ihrem Glauben) faktisch übertragen ist 'nach dem Mass menschlichen Einsicht und menschlichen Vermögens' für zeitliches Recht und zeitlichen Frieden, für eine äusserliche, relative, vorläufige Humanisierung der menschliche Existenz zu sorgen” (p. 14). 
German army and ban the use of military force could have. They are only interested in obeying what they believe the will of God is, and they are quite happy to leave the responsibility for the consequences of their decisions to the almighty God who in his providence determines the outcome of events in accordance with his will.

In opposition to the Ethics of Conviction Weber proposed an Ethics of Responsibility (German: "Verantwortungsethik"). In contrast to politicians who adhere to an Ethics of Conviction politicians who adhere to an Ethics of Responsibility would be willing to:

- take full personal responsibility for deciding on the right political actions;

- take the specific nature of politics as a separate life sphere with its own principles and demands seriously (including what Weber calls "die Sache" of politics: The maintenance of order);

- take their particular role responsibility as politicians - to do what is needed to maintain order - and not only what they regard as their moral responsibility, seriously; and

- seriously consider the consequences their political decisions could have on the political power play, before taking and implementing such decisions.

In my opinion Weber has convincingly demonstrated that ethics - and that includes Christian ethics - is not a simple matter of mechanically applying only moral principles in particular circumstances. It is a much more complicated matter in which a particular person or group of persons have to take responsibility for thoroughly analysing the concrete situation and deliberating the possible consequences of different options for action, but also for weighing up different value systems that are in play, before making a decision on the right action. It is especially important to not only consider moral values based on the Bible and to ignore the functional values that are valid in the different social systems (for example in economy: Efficiency and productivity), and the cultural values of a particular people (for example the "ubuntu" values of African people).

What I would like to suggest is that the adequate, contemporary Christian social ethics that we as Reformed ethicists need in the South African society, cannot but be an Ethics of Responsibility (cf. De Villiers 2003:23-38). It is only when Christian social ethics is conceived as Ethics of Responsibility that justice can be done to both the Christian moral tradition and the achievements of modernisation, including the development of modern societies into relatively independent social systems. Only then would it also be possible to take adequate account in Christian social ethics of the different cultures of the peoples of South Africa.

This is not to deny that there are certain aspects of Weber's view on the Ethics of Responsibility that are problematic. Weber uses the image of polytheism to describe the different value systems the Ethics of Responsibility has to take account of. ${ }^{5}$ This image, however, suggests that the system of moral values has no priority over the other value systems, but has to compete on an equal footing with these other value systems for recognition. From a Christian perspective the central moral values that we believe are an expression of the moral will of the one true God do have some priority. It is true that this priority is not an absolute one, in the sense that moral values always completely replace functional values that seem to be in tension with it. This was, unfortunately, the way in which the priority of moral values was for a long period understood in the history of the Christian church. For more than a millennium the Biblical prohibition against usury (Deut. 23:19), for example, was used to condemn all imposition of interest, even after it became

5 See Weber's Gesammelte Aufsätze zur Wissenschaftslehre, pp. 507, 603. 
clear that the imposition of interest is an economically desirable practice. We should rather acknowledge that functional and cultural values are, for the most part, not in opposition to moral values, but, as valid in their own right, stand to them in a complementary relationship. The challenge that we are faced with in a Christian Ethics of Responsibility is to facilitate between the moral, functional and cultural value systems in such a way that they are all accommodated optimally. ${ }^{6}$

This is not to deny that functional and cultural values can sometimes be in strong opposition to moral values that are central to Christians. This is, for example, the case when functional values that are valid in a particular social sphere, start to play an imperialistic role in other social systems. A valid economic value like competition can cause havoc if it becomes dominant in the family. For this reason William Schweiker is of the opinion that the role of moral and religious values over against other values is primarily a limiting one: To prevent them from claiming validity outside their sphere of competence (Schweiker 2000:128-139). Schweiker seems to imply that the difference between moral and other values lies in the fact that moral values have trans-systemic validity, while other values only have intra-systemic validity. If he is right the trans-systemic nature of moral values may be one way of conceiving their priority with regard to other values. Their priority comes into play not only when functional and cultural values overstep the limits of their sphere of competency, but also when perverted versions of them become prevalent within social systems. For example, even in business the 'dog eats dog' interpretation of competition is never acceptable from a Christian moral perspective. In other words, the priority of moral values consists - at least partly - in the fact that they play an indispensable limiting role with regard to other values, both on the borders of social systems and within them.

The achievement of a strong Christian consensus on what a good society in South Africa entails

Christians cannot effectively contribute to the transformation of the South African society if they are not strongly motivated to do so or have disparate visions on the good South African society. In my opinion it is part of the vocation of the Christian ethicist in South Africa to help provide Christians with a strong motivation to contribute constructively to the transformation of the South African society and to work towards the achievement of a strong consensus on what a good society in South Africa entails. These two tasks, of course, go hand in hand. Christians will only be motivated to work for the transformation of society if they are inspired by a common Christian vision of the good South African society.

The crucial question is: How can such a common Christian vision be achieved? It is not only undesirable, but in the present South African society also impossible, to impose a particular Christian social vision in an authoritarian way on other Christians and nonChristians as it was often done in the past. The only way is to strive to achieve a strong Christian consensus through intense, but open dialogue. The Christian ethicist has to stimulate the debate on the good South African society in the media, her church

6 The need to acknowledge "that human beings do not develop theological convictions free of the influence of environments, subsystems, and associations in which they live and in which they commit themselves to action", while at the same time preserving "theology within communities of faith from being diverted from its actual content and object and from losing sight of speech about God" is also stressed by Michael Welker (2000:120-121). 
denomination and especially in ecumenical organisations. In my opinion she also has to propagate the idea that covenants should be concluded between church members on a denominational level and between church denominations on an ecumenical level on the basis of agreements that have been reached. I agree with the Swiss theologian Johannes Fischer that the threat moral dissensus in modern societies poses to the normative status of morality can only be overcome by exercising the meta-responsibility to conclude covenants on the basis of moral consensus that has been reached through dialogue (cf. Fischer 1994:110-123). For Christians this includes the responsibility to contribute to the conclusion of moral covenants both within the Christian community and in society at large.

We can distinguish different levels in the debate on a good South African society on which Christians should strive to reach a strong consensus:

- The level of the identification and definition of the major issues and challenges in the South African society. A shared Christian vision of a good society in South Africa can only be formulated if Christians agree on what the major issues and challenges in our society are. At the South African Christian Leadership Assembly (SACLA) held in Pretoria from 7 to 12 July 2003 delegates from a representative number of churches in South Africa came a long way in agreeing on what the major issues are. They identified seven so-called "giants" that need to be killed in a sustained national process of action and advocacy, through Christians in the church and broader society: Crime, poverty, unemployment, racism, gender/sexual discrimination, the family in crisis and HIV/Aids. The challenge that lies ahead of churches is to also reach consensus on which manifestations of these issues have priority and on what their causes are. It would, for example, not help if churches agree that poverty is a major issue, but some of them find the increase in poverty among white people the most pressing, whilst others are of the opinion that it is rather the case with poverty among black people in the rural areas. It would also be of no avail if some churches refuse to take the contribution of apartheid to poverty into account, whilst others insist on doing so.

- The level of the acceptance of a normative Biblical basis for the development of a Christian vision of a good South African society. To reach sufficient consensus among Christians in this regard is quite a challenge, because they often interpret the Bible differently as a result of the different theological traditions they stand in (Smit 1987:33). On the one extreme of the spectrum of views on the use of the Bible in Christian ethics is the fundamentalist view that the normative character of the Bible is only recognised by accepting that all Biblical guidelines are still valid today. On the other extreme is the relativist view that Biblical guidelines have no contemporary validity as a result of the fact that they are culturally determined. One of the biggest present challenges the Reformed ethicist faces is to convince fellow Christians to abandon these all or nothing approaches. On the one hand we have to admit that many of the specific Biblical guidelines cannot be directly applied to contemporary societies (for example, the prohibition of usury in Deut. 23:19 and guidelines regarding the jubilee), or are just not acceptable anymore (for example guidelines regarding the death penalty in the Old Testament and the submissive conduct that was expected of women in Israel and the early church). We also have to admit that not all the normative elements needed for the construction of a Christian vision of a good contemporary society can be found in the Bible.

On the other hand we can profess that the Bible still provides basic moral orientation to contemporary Christians (Huber 1999:156; Koopman \& Vosloo 2002:8-10). Certain moral principles in the Bible like the love commandment, the Ten Commandments and 
justice (including the obligation to provide special care to the weak in society) form such an integral part of the basic identity of the faith community that they just have to be taken as point of departure in the formulation of a Christian social vision. The Old Testament vision of God's Kingdom of Peace ("shalom") and the New Testament one of the New Earth and the New Heaven can provide inspiration and stir the moral imagination. Normative analogies can be drawn between the new life in Christ of the church sketched in the New Testament (for example, the realisation of visible unity, joining all natural and cultural differences into life-giving richness and of real reconciliation, overcoming deep divisions and structures of alienation) and the new society that we Christians should strive for in South Africa (Smit 2002:8). And even culturally determined Biblical guidelines that are not directly applicable anymore can serve as normative paradigms, because they are expressions of more general moral intentions that are still applicable today. An example is the jubilee guidelines of the Old Testament that played an important role in recent debates on the canceling of the debts of the poorest developing countries. Although they are not applicable anymore in their specific formulation, the normative intention of care for those who are entangled in debt that they express, is just as valid today.

- The level of the formulation of a Christian vision of a good South African society. On the basis of insight into the major issues in the South African society and the relevant normative elements in the Bible positive content must finally be given to the Christian vision of a good South African society. The idea is not to formulate a comprehensive programme, complete with policy and strategy recommendations, but rather to provide an integrated and inspiring model of the values that should guide us in the public sphere and of the desirable end states in the South African society we should strive for. This is a complex and creative exercise that cannot be undertaken by Christian ethicists alone. The reason is that insights from academic disciplines other than theology have necessarily to be incorporated. Visions of the ideal South African society developed in social spheres other than the religious like the economy and politics (for example, the Reconstruction and Development Programme of the ANC) have to be engaged with. Justice should be done not only to Biblical moral values, but also to values and goals that are recognised in these other social spheres. All of this can only be done responsibly if representatives from other academic disciplines and other social spheres are involved. The Reformed ethicist, however, has a special responsibility to instigate such an interdisciplinary initiative. She also has the responsibility to see to it that the results of the initiative is as widely disseminated as possible to facilitate the optimal consensus on a Christian vision of a good South African society. Consensus formation can be enhanced even more if the institutional backing of recognised ecumenical organisations can be obtained.

\section{The effective translation and promulgation of the Christian vision of a good} South African society in broader society

The crucial question with regard to the effective promulgation of the Christian vision of a good South African society is: Should it be promulgated in the broader South African society in its distinctively Christian form, or is some translation of it needed to ensure its wider acceptance?

In his book Waakzaam en nuchter: Over Christelijke ethiek in een democratie (English translation of the title: Vigilant and level-headed: On Christian ethics in a democracy) the Dutch Reformed theologian Gerrit de Kruijf argues that it is irresponsible to suffice with a 
distinctively Christian vision. The Barthian approach of prophetic Christian witness in public on political and economic matters is, in his opinion, not appropriate in contemporary liberal democracies (De Kruijf 1994:40-52; 236-240). He does not deny that there may come a moment that faith in Christ cannot tolerate developments within a particular liberal democratic state and that faithfulness to Christ and political disobedience may coincide. Such a "status confessionis" is, however, something extraordinary (De Kruijf 1994:182). In normal circumstances the witness or prophetic approach is incompatible with a liberal democracy, because it insists that the Christian view should be the basis of policy and legislation and that other views need not be taken into account. In addition, it is not a constructive approach, because the church knows in advance that its prophetic Christian witness cannot be accepted in plural democracies as basis for policy and legislation. If churches and individual Christians want to responsibly contribute to consensus and policy formation they should not make pronouncements on societal issues on the basis of their own "thick" or strong Christian morality, but do so rather on the basis of the "thin" cultural values shared by all in plural societies (De Kruijf 1994:188; 195). ${ }^{7}$

The social scientist Peter Beyer has a rather similar view in this regard. He is of the opinion that the predominance of globalisation as the contemporary outcome of the process of modernisation does not necessarily mean that the public role of religion has been played out. The reason for this is that global instrumental systems such as the capitalist economic, sovereign state, scientific, health and educational systems are totalising, in the sense that they are applicable to anything in their environment, but not all-encompassing, because there is much that they exclude (Beyer 2001:266). Among these are the meaning and thematising of the social whole, the 'private sphere' or 'life world' and many problematic effects of their operation. This is where religion, as the one mode of communication that is in principle both totalising and encompassing, can and does play an important role. It can and does serve as a kind of system specialisation that deals with what, from the perspective of the dominant functional systems, are residual matters. Religion's role in this regard is typically 'anti-systemic' in the sense that religious adherents, leaders and professionals tend to see their communication as essential because it addresses the problems that the dominant systems either leave out or create without solving. 'Anti-systemic' may mean against the dominant structures and values of emerging global society, as is clearly the case with some contemporary forms of fundamentalist religion. The 'anti-systemic' role of religion can, however, also be 'pro-systemic' in the sense that liberal moral values like equality and freedom, which are - in Beyer's opinion - inherent to the social systems of modernity, are taken as point of departure in criticising the negative effects of these systems, as is the case in liberal Christianity (e.g. the WCC) (Beyer 2001:273).

Both De Kruijf and Beyer affirm that the church can and should play a constructive role in public debates on social issues. They seem to imply that this can only be done if the church is willing to suspend its own distinctive Christian morality and base its public contribution to a debate on the good society entirely on common values. De Kruijf and Beyer would probably argue that the church should not have any problems with such a view, because there is a great deal of overlapping between Christian and cultural values. This may to some extent be the case in Western societies. In the case of many non-Western

See for the distinction "thick" and "thin" used with regard to morality and ethics: Walzer, M, Thick and thin: Moral argument at home and abroad (1994), xi, footnote 1 . Walzer utilises the term "thick" to point to a kind of moral argument that is "richly referential, culturally resonant, locked into a locally established symbolic system or network of meanings". "Thin" is simply the contrasting term. 
societies, even non-Western societies with liberal constitutions, however, this overlapping is often not as strong. And even in Western societies it has lessened over the last century. As Robert Bellah and his co-authors in Habits of the heart demonstrated with regard to the American society: The enormous historical influence of Biblically inspired Christian values on the moral consensus in that society is being strongly undermined by the utilitarian individualism enhanced by the dominating economic system of capitalism (Bellah 1996:142-163). One suspects that the same undermining processes are taking place in societies in the previously Christian Europe.

I am personally of the opinion that De Kruijf's and Beyer's views are - in the case of the South African society - only valid with regard to certain aspects of the participation of the church in public debate. De Kruijf is right in saying that Christians can hardly expect legislation in liberal democracies to be based on strong Christian values. Legislation - for example on abortion - has to allow different-minded groups and individuals to act in accordance with their own consciences. Christians can, however, strive to shift the moral consensus in society to bring it more in harmony with Christian moral values and in this way indirectly influence legislation. They can do it by using arguments for their views that can also be accepted by non-Christians. In a society like South Africa it can also be done by giving adequate publicity to official church views on societal issues. The majority of South Africans are Christian and are therefore perfectly capable to understand typical Christian arguments.

We also have to take into account that the South African society is and has always been a strongly religious society. In a 1995 World Values Study, $81 \%$ of South African respondents reported that they considered themselves to be religious, with $98 \%$ of those surveyed stating they believed in God, and 70.7\% rating God's importance to them as 10 on a scale of 1-10 (where 10 equals "very important") (Venter 2002:174). The different religions share the view that religions should be allowed to play a public role in society on a fair basis. In the South African constitution recognition was given to this shared conviction in Section 15, which stipulates that religious observances are allowed in state institutions on a fair basis. The separation between religion and state in the South African democracy is therefore not such a hard one. Some room is given for religions to play a public role and exert a public influence.

Something else that we have to take account of is that public discourse on moral issues and the good society is not only about government policies and legislation. It is, inter alia, also about the way business is conducted by private companies, new technologies developed by scientists and companies and new trends in structuring intimate relationships. Many of these moral issues are discussed in the media. Journalists and the public expect churches and theologians to have their own distinctively Christian views on these issues. In fact, that is often the main reason why they are consulted by the media. Christians also become involved in the discussion of ethical issues in their workplace. To the extent that businesses are owned by Christians or are managed by them, or exclusively serve Christians, they also there have the opportunity to take a Christian stance on moral issues. ${ }^{8}$ It is, however, true that increasingly people from different religious and cultural backgrounds can be found in the South African workplace. Even there it becomes in-

8 In a recent article Hannes Britz and I argued that even an Internet Service Provider can be based on Christian values when it is owned by Christians and has as goal to provide service specifically to Christians (Britz \& De Villiers 2003: 348-355). 
reasingly necessary to use ethical arguments non-Christians can agree with and to seek moral consensus among people with different views of life.

Reformed ethicists in South Africa also have to take into account that our society is an African one. Still only a minority of the population are predominantly Westerly orientated, with predominantly individualist values and attitudes. The majority of the African population still adhere to values and display attitudes that are, to a lesser or greater extent, communal in nature. It may be that we, in the end, have to conclude that the strong privatisation of religion and even the sharp differentiation of the social systems that are typical of Western societies, do not apply to the same extent to our new democracy. The work of some social scientists points in this direction. Although J Casanova accepts the differentiation of social systems in Western societies as valid, he argues that the privatisation of religion is a historical option, but not a necessary one. It was the authoritarian role of religion in Europe that facilitated the privatisation of religion. The exclusive limitation of religion to the private domain of life did not necessarily flow from the factors that gave rise to secularisation. The public role of religion may therefore - in his view - be compatible with democratic institutions and religion could still play an important role in civil society by humanising the rational systems of modernity (Casanova 1994:39).

In discussing Casanova's views A Tayob, a lecturer in religious studies at the University of Cape Town, argues that not only the privatisation of religion, but also the differentiation that are typical of Western societies, have no counterpart in postcolonial societies in Africa. The reason is that Casanova's prime factors of differentiation: Religious reformation, state formation, capitalism and scientific developments, are either absent or distorted in these societies. The lack of differentiation does not, however, translate in religion playing a transforming role in postcolonial African states. The opposite is rather the case. Unlike Europe, where debates have raged within religious traditions about the transformation of society, critical debates are almost non-existent. Religions in post-independent societies seem happy to demand a fair share of the state's support and resources in exchange for loyalty (Tayob 2002:12). In other words, although the weaker privatisation of religion and the weaker differentiation of social systems in African societies seem to provide the churches more scope to contribute to the transformation of society, it can also be a hindrance to such a contribution when it leads to cosy relationships between churches and governments based on mutual interests.

\section{Conclusion}

I have tried in this paper to draw out the implications of the Reformed conviction that Christians are called by God to contribute to the transformation of society for the vocation of Reformed ethicist in the present South African society. This conviction was taken for granted by Reformed Christians in the previous political dispensation, but has lost much of its legitimacy since the advent of the new liberal democracy in 1994. In my opinion its legitimacy can only be restored by reconstructing or reforming the traditional transformation approach and by developing a more inclusive version that suits the contemporary context. One may say that contributing to the development and the implementation of an inclusive transformation approach is the most important part of the vocation of Reformed ethicist in the present South African society. It entails contributing to the development of an adequate, contemporary Christian social ethics, the formulation of a Christian vision of a good society in South Africa based on a strong Christian consensus and the effective translation and promulgation of this Christian vision in broader society. This poses a most formidable task for the Reformed ethicist. Fortunately, however, she is not alone in this 
task. She shares this task with many others in the church of Christ, amongst others, fellow theologians, social scientists, politicians and business people. If God wills they can together play an important role in the transformation of the South African society towards a better society.

\section{BIBLIOGRAPHY}

Barth, K 1946. Christengemeinde und Bürgergemeinde. Zollikon-Zürich: Evangelischer Verlag.

Bellah, RN; Madsen, R; Sullivan, WM; Swidler, A \& Tipton, SM 1996. Habits of the heart: Individualism and commitment in American life. Berkeley: University of California Press.

Beyer, P 2001. The global environment as a religious issue: a sociological analysis, in D Herbert (ed.), Religion and social transformations. Aldershot: Ashgate, 261-212.

Boesak, A 1984. Black and Reformed: Apartheid, liberation and the Calvinist tradition. Johannesburg: Skotaville Publishers.

Britz, JJ \& De Villiers, DE 2003. Die morele verantwoordelikheid van internetdiensverskaffers: 'n Christelik etiese perspektief, in Verbum et Ecclesia 24(2), 333-358.

Burger, C 2001. Ons weet aan wie ons behoort: Nuut gedink oor ons gereformeerde tradisie. Wellington: Lux Verbi.

Casanova, J 1994. Public religions in the modern world. Chicago: University of Chicago Press.

De Villiers, DE 1984. Kerklike standpunte sedert die instelling van die wette, in E. de Villiers \& J Kinghorn (eds.). Op die skaal: Gemengde huwelike en ontug. Cape Town: Tafelberg, 54-77.

De Villiers, DE 1999. Die NG Kerk en die oorgang na 'n nuwe Suid-Afrika, in Skrif en Kerk 20(1), 15-38.

De Villiers, DE 2001. The influence of the DRC on public policy during the late 1980's and 1990's, in Scriptura 76, 51-61.

De Villiers, DE 2003. A Christian ethics of responsibility: Does it provide an adequate theoretical framework for dealing with issues of public morality?, in Scriptura 82, 23-38.

Durand, J 2002. Ontluisterde wêreld: Die Afrikaner en sy kerk in ' $n$ veranderende wêreld. Wellington: Lux Verbi.

Fischer, J 1994. Leben aus dem Geist: Zur Grundlegung christlicher Ethik. Zürich: Theologischer Verlag.

Huber, W 1999. Kirche in der Zeitenwende: Gesellschaftlicher Wandel und Erneuerung der Kirche. Gütersloh: Gütersloher Verlagshaus.

Koopman, N \& Vosloo, R 2002. Die ligtheid van die lig: Morele oriëntasie in 'n postmoderne tyd. Wellington: Lux Verbi.

Leith, JH 1992. The ethos of the Reformed tradition, in DK McKim (ed.), Major themes in the Reformed tradition. Grand Rapids: Eerdmans, 5-18.

Lubbe, G 2002. Religio-political changes in South Africa, in D Kritzinger (ed.), No quick fixes: Challenges to mission in a changing South Africa. Pretoria: IMER, 61-69. 
Moltmann, J 1974. Man: Christian anthropology in the conflicts of the present. London: SPCK.

Niebuhr, HR 1951. Christ and culture. New York: Harper \& Row. Proceedings of the General Synod of the DRC 1998.

Schweiker, W 2000. Responsibility in the world of Mammon: Theology, justice and transnational corporations, in: ML Stackhouse \& PJ Paris (eds.). God and globalization, Volume 1: Religion and the powers of the common life. Harrisburg, Pennsylvania: Trinity Press International.

Smit, DJ 1998. Wat beteken 'Gereformeerd'? in: WA Boesak \& PJA Fourie (eds.). Vraagtekens oor Gereformeerd. Belhar: LUS Uitgewers, 20-37.

Smit, DJ 2002. Comments and questions (unpublished presentation on a research project under the auspices of the Center for Theological Inquiry, Princeton New Jersey, USA).

Tayob A 2002. Religion, culture and identity in a democratic society, in Journal for the Study of Religion 15(2), 5-13.

Tomlinson, J 1999. Globalization and culture. Chicago: University Press.

Troeltsch, E 1981. The social teaching of the Christian churches, Volume 2. Chicago: University of Chicago Press.

Venter, D 2002. What is sociology that religionists should be mindful of it? The relevance of the sociology of religion for studying change in South Africa, in Journal for the Study of Religion 15(2), 167-189.

Walzer, M 1994. Thick and thin: Moral argument at home and abroad. Notre Dame \& London: University of Notre Dame Press.

Weber, M 1968. Gesammelte Aufsätze zur Wissenschaftslehre. 3. Aufgabe. Tübingen: JCB Mohr (Paul Siebeck).

Weber, M 1994. Wissenschaft als Beruf 1917/1919. Politik als Beruf 1919: Studienausgabe. Tübingen: JCB Mohr (Paul Siebeck).

Welker, M 2000. Is theology in public discourse possible outside communities of faith?, in LE Lugo (ed.). Religion, pluralism, and public life: Abraham Kuyper's legacy for the twenty first century. Grand Rapids: Eerdmans, 110-122. 